\title{
Mammalian Mitochondrial DNA Evolution: A Comparison of the Cytochrome $b$ and Cytochrome $c$ Oxidase II Genes
}

\author{
Rodney L. Honeycutt, ${ }^{1}$ Michael A. Nedbal, ${ }^{1}$ Ronald M. Adkins, ${ }^{1} *$ Laura L. Janecek ${ }^{1,2}$ \\ ${ }^{\mathrm{I}}$ Department of Wildlife \& Fisheries Sciences, Texas A\&M University, 210 Nagle Hall, College Station, TX 77843, USA \\ ${ }^{2}$ Savannah River Ecology Laboratory, University of Georgia, Aiken, SC 29801, USA
}

Received: 10 June 1994 / Accepted: 10 October 1994

\begin{abstract}
The evolution of two mitochondrial genes, cytochrome $b$ and cytochrome $c$ oxidase subunit II, was examined in several eutherian mammal orders, with special emphasis on the orders Artiodactyla and Rodentia. When analyzed using both maximum parsimony, with either equal or unequal character weighting, and neighbor joining, neither gene performed with a high degree of consistency in terms of the phylogenetic hypotheses supported. The phylogenetic inconsistencies observed for both these genes may be the result of several factors including differences in the rate of nucleotide substitution among particular lineages (especially between orders), base composition bias, transition/transversion bias, differences in codon usage, and different constraints and levels of homoplasy associated with first, second, and third codon positions. We discuss the implications of these findings for the molecular systematics of mammals, especially as they relate to recent hypotheses concerning the polyphyly of the order Rodentia, relationships among the Artiodactyla, and various interordinal relationships.
\end{abstract}

Key words: Cytochrome $b-$ Cytochrome $c$ oxidase II - Mammals - Mitochondrial DNA - Molecular evolution

* Present address: Museum of Zoology, University of Michigan, 1109 Geddes, Ann Arbor, MI 48109, USA

Correspondence to: R.L. Honeycutt

\section{Introduction}

The mitochondrial cytochrome $b(\mathrm{COB})$ and cytochrome $c$ oxidase subunit II (COII) genes have been used in several recent molecular systematic studies of rodents (DeWalt et al. 1993; Ma et al. 1993; Thomas and Martin 1993), ungulates (Irwin et al. 1991; Irwin and Wilson 1992; Miyamoto et al. 1994), marine mammals (Irwin and Arnason 1994), primates (Ruvolo et al. 1991; Disotell et al. 1992; Adkins and Honeycutt 1994), and eutherian mammal orders (Adkins and Honeycutt 1991, 1993; Honeycutt and Adkins 1993). The COB gene, in particular, has been used extensively in the investigation of systematic relationships among vertebrates, and the COII gene studies have focused primarily on primates and their presumed relatives. In this paper we examine patterns of nucleotide sequence variation in the COB and COII genes, with an emphasis on determining relationships within and among mammalian orders. New nucleotide sequence data for the COII gene are combined with existing information from both COB and COII, and the similarities and differences among resultant gene phylogenies are evaluated. In addition, rates of nucleotide substitutions, differences in codon usage, and base composition bias are examined for both genes, using representative taxa from the mammalian orders Rodentia and Artiodactyla.

\section{Materials and Methods}

Mitochondrial Genes Examined. A total of $35 \mathrm{COB}$ genes and $37 \mathrm{COII}$ genes were examined for six orders of eutherian mammals as well as 
one metatherian order (Table 1). In the case of the new COII sequences reported in this paper, mitochondrial DNA (mtDNA) was isolated using cesium chloride/propidium iodide gradient centrifugation (Brown 1980), and the entire COII gene was amplified with primers H8320 and L7553 (see Adkins and Honeycutt 1994) by the polymerase chain reaction (PCR) using the parameters $95^{\circ} \mathrm{C}$ denaturation $(1 \mathrm{~min}), 45^{\circ} \mathrm{C}$ annealing $(1 \mathrm{~min})$, and $72^{\circ} \mathrm{C}$ extension $(1.25 \mathrm{~min})$ for 30 cycles. The amplified COII genes were either sequenced directly using singlestranded PCR products (Allard et al. 1991a) or the double-stranded product was ligated into the pBluescript plasmid and then sequenced. In both cases sequencing followed that of Kraft et al. (1988). Because of the inherent error rate of Taq polymerase (Saiki et al. 1988; Tindall and Kunkel 1988; Keohavang and Thilly 1989), at least two clones were sequenced for each taxon. In two cases (Geomys, Perognathus) a single sequence discrepancy was found. A third clone was sequenced in each case, and the base present in two clones was assumed to be correct.

\section{Data Analysis}

Phylogenetic analyses were performed by two methods--maximum parsimony as implemented by PAUP 3.1 (Swofford 1993) and neighbor-joining (Saitou and Nei 1987) as implemented by the MEGA program (Kumar et al. 1993). Maximum-parsimony analyses were conducted using both equal and unequal character weighting. Equal weighting consisted of all substitutions regardless of codon position being given equal weight. Unequal weighting schemes included the use of transversions only as well as a procedure whereby differential weights were assigned to each codon position (e.g., transversions only at third position, all substitutions at second position, and all substitutions at first position with changes involving leucine at the first position recoded as $\mathrm{Y}$, the generic symbol for a pyrimidine). Neighbor-joining analyses were conducted using pairwise distance estimates based on several models (Jukes and Cantor 1969; Kimura 1980; Tajima and Nei 1984; Tamura and Nei 1993). In addition, gamma distances were estimated using MEGA (Kumar et al. 1993) for all the above models except Tajima and Nei (1984). We chose to examine relationships using these various distances in an effort to circumvent assumptions specific to any one model (e.g., rate of nucleotide substitution assumed to be the same for all sites, all nucleotide frequencies equal to 0.25 , and no transition bias).

Support for individual nodes on a phylogenetic reconstruction was evaluated using both the bootstrap option (Felsenstein 1985) and the Bremer support index (Bremer 1988), the number of extra steps required to break up a clade. Tests for rate heterogeneity among divergent taxa were evaluated using a relative rate test (Mindell and Honeycutt 1990). Codon usage and base composition values were obtained by the sequence analysis program MacVector 3.5 (International Biotechnologies, Inc.) and MEGA (Kumar et al. 1993).

\section{Results and Discussion}

\section{Interordinal Phylogenetic Comparisons}

A total of 18 species of eutherian mammals were used in the interordinal comparisons, with a marsupial outgroup (either Didelphis or Monodelphis). These 18 species represented six eutherian orders including (1) Primates (Homo and Galago); (2) Carnivora (Phoca); (3) Lagomorpha (Oryctolagus): (4) Cetacea (Balaenoptera); (5) Rodentia (Geomys, Cratogeomys, Sciurus, Cavia, Mus, Rattus, and either Hystrix or Georychus); and (6) Artiodactyla (Bos, Capra, Odocoileus, Antilocapra, Sus, and either Cervus or Dama).
Table 1. Specimens examined

\begin{tabular}{|c|c|c|}
\hline Taxa & $\mathrm{COB}^{\mathrm{a}}$ & $\mathrm{COII}^{\mathrm{a}}$ \\
\hline \multicolumn{3}{|l|}{ Infraclass Eutheria } \\
\hline \multicolumn{3}{|l|}{ Order Artiodactyla } \\
\hline \multicolumn{3}{|l|}{ Family Antilocapridae } \\
\hline Antilocapra americana & 10 & 13 \\
\hline \multicolumn{3}{|l|}{ Family Bovidae } \\
\hline Bos gaurus & & 18 \\
\hline Bos grunniens & & 18 \\
\hline Bos indicus & & 18 \\
\hline Bos javanicus & & 18 \\
\hline Bos taurus & 3 & 3 \\
\hline Boselaphus tragocamelus & & 13 \\
\hline Bubalus depressicornis & & 18 \\
\hline Capra hircus & 10 & 13 \\
\hline Damaliscus dorcas & & 18 \\
\hline Gazella spekei & & 18 \\
\hline Syncerus c. caffer & & 18 \\
\hline Syncerus c. nanus & & 18 \\
\hline Tragelaphus imberbis & & 18 \\
\hline Ovis aries & 10 & \\
\hline \multicolumn{3}{|l|}{ Family Camelidae } \\
\hline Camelus dromedarius & 10 & \\
\hline \multicolumn{3}{|l|}{ Family Cervidae } \\
\hline Cervus unicolor & & 13 \\
\hline Dama dama & 10 & \\
\hline Odocoileus herninous & 10 & \\
\hline Odocoileus virginianus & & 18 \\
\hline \multicolumn{3}{|l|}{ Family Giraffidae } \\
\hline Giraffa camelopardalis & 10 & \\
\hline \multicolumn{3}{|l|}{ Family Tragulidae } \\
\hline Tragulus napu & 10 & \\
\hline \multicolumn{3}{|l|}{ Family Suiidae } \\
\hline Sus scrofa & 10 & 18 \\
\hline Tayassu tajacu & 10 & \\
\hline \multicolumn{3}{|l|}{ Order Carnivora } \\
\hline Phoca vitulina & 5 & 5 \\
\hline \multicolumn{3}{|l|}{ Order Cetacea } \\
\hline Balaenoptera physalus & 4 & 4 \\
\hline \multicolumn{3}{|l|}{ Order Lagomorpha } \\
\hline Oryctolagus cuniculus & 9 & 17 \\
\hline \multicolumn{3}{|l|}{ Order Primates } \\
\hline \multicolumn{3}{|l|}{ Family Galagidae } \\
\hline Galago crassicaudatus & 16 & \\
\hline Galago senegalensis & & 1 \\
\hline \multicolumn{3}{|l|}{ Family Hominidae } \\
\hline Homo sapiens & 2 & 2 \\
\hline Order Rodentia & & \\
\hline Suborder Sciurognathi & & \\
\hline Family Geomyidae & & \\
\hline Cratogeomys c. castanops & 7 & 18 \\
\hline Cratogeomys c. tamaulipensis & 7 & \\
\hline Cratogeomys fumosus & 7 & \\
\hline Cratogeomys goldmani & 7 & \\
\hline Cratogeomys gymnurus & 7 & \\
\hline Cratogeomys merriami & 7 & \\
\hline Geomys bursarius & 7 & 18 \\
\hline Pappogeomys bulleri & 7 & \\
\hline Family Heteromyidae & & \\
\hline Perognathus flavus & & 18 \\
\hline Family Sciuridae & & \\
\hline Marmota flaviventris & 15 & \\
\hline Sciurus caroliensis & 15 & 18 \\
\hline Spermophilus columbianus & 15 & \\
\hline Spermophilus lateralis & 15 & \\
\hline Spermophilus richardsoni & 15 & \\
\hline Spernophilus tridecemlineatus & 15 & \\
\hline
\end{tabular}


Table 1. Continued

\begin{tabular}{|c|c|c|}
\hline Taxa & $\mathrm{COB}^{\mathrm{a}}$ & COII $^{\mathrm{a}}$ \\
\hline \multicolumn{3}{|l|}{ Family Muridae } \\
\hline Acomys willsoni & & 18 \\
\hline Apodemus sylvaticus & & 18 \\
\hline Malacothrix typica & & 18 \\
\hline Meriones shawi & & 18 \\
\hline Microtus pennsylvanicus & & 14 \\
\hline Mus domesticus & 6 & 6 \\
\hline Peromyscus banderanus & & 18 \\
\hline Rattus norvegicus & 8 & 8 \\
\hline \multicolumn{3}{|l|}{ Suborder Hystricognathi } \\
\hline \multicolumn{3}{|l|}{ Family Bathyergidae } \\
\hline Georychus capensis & & 18 \\
\hline \multicolumn{3}{|l|}{ Family Caviidae } \\
\hline Cavia apera & & 18 \\
\hline Cavia porcellus & 12 & \\
\hline \multicolumn{3}{|l|}{ Family Hystricidae } \\
\hline Hystrix africaeaustralis & 12 & \\
\hline \multicolumn{3}{|l|}{ Infraclass Metatheria } \\
\hline Didelphis virginiana & & 11 \\
\hline Monodelphis domestica & 12 & \\
\hline
\end{tabular}

${ }^{a}$ Numerical designations for sequences used: 1 . Adkins and Honeycutt 1991. 2. Anderson et al. 1981. 3. Anderson et al. 1982. 4. Arnason et al. 1991. 5. Arnason and Johnsson 1992. 6. Bibb et al. 1981. 7 DeWalt et al. 1993. 8. Gadaleta et al. 1989. 9. Irwin and Arnason 1994. 10. Irwin et al. 1991. 11. Janke et al. 1994. 12. Ma et al. 1993. 13. Miyamoto et al. 1994. 14. Pumo et al. 1992. 15. Thomas and Martin 1993. 16. Anne Yoder, pers comm. 17. Genbank X64107. 18. This paper

The resultant COB and COII gene phylogenies, derived from the maximum parsimony and neighborjoining analyses, had several features in common regardless of the weighting scheme and distance estimate chosen (Fig. 1 and Table 2). These features are pertinent to several recent issues concerned with ordinal-level relationships among eutherian mammals. First, several recent molecular studies (Graur et al. 1991; Li et al. 1992; Graur 1993; Ma et al. 1993), using both amino acid and nucleotide sequence data for a limited number of taxa, have not supported the monophyly of the order Rodentia, with the hystricognath rodents (especially the South American caviomorphs) representing a separate lineage from the sciurognath rodents (e.g., mice, rats, squirrels, etc.). We attempted to avoid the pitfalls of many earlier studies by increasing the number of rodent taxa in the analyses. The COB and COII gene phylogenies, however, have complicated the issue of rodent monophyly even further, with as many as four independently evolving lineages observed (Fig. 1). These molecular findings are totally incongruent with the morphological data, which strongly support rodent monophyly (Allard et al. 1991b; Luckett and Hartenberger 1993).

Second, the monophyly of the order Artiodactyla was not supported by either gene. The COII gene placed the order Cetacea closer to ruminants than Sus, a nonruminant artiodactyl, and several $\mathrm{COB}$ gene analyses revealed a sister-group relationship between cetaceans and Sus
(Fig. 1 and Table 2). Both genes also suggested a sistergroup relationship between the order Carnivora and the Artiodactyla/Cetacea clade, which included Sus. These findings are congruent with several independent studies including a detailed analysis by Graur and Higgins (1994) that examined both nuclear and mitochondrial genes and an examination of several complete mitochondrial genomes of mammals (Arnason and Johnsson 1992; Honeycutt and Adkins 1993). Although the placement of Carnivora is somewhat incongruent with morphological evidence, the association of the cetaceans as sister to ruminant artiodactyls to the exclusion of nonruminants is not contradicted by morphological evidence (Honeycutt and Adkins 1993; Graur and Higgins 1994).

Third, recent morphological evidence (Novacek 1992; Luckett and Hartenberger 1993) and at least one molecular study of mitochondrial genes from four orders of mammals (Pesole et al. 1991) support a monophyletic Glires, a superorder containing Rodentia and Lagomorpha (rabbits). The COB and COII gene trees do not support these findings and are consistent with a large number of other molecular studies that find no support for the monophyly of Glires (reviewed by Honeycutt and Adkins 1993). In fact, several of these molecular studies, including one total evidence tree for $\mathrm{COB}$ and COII (transversion only analysis), support a closer relationship between rabbits and primates. The difference between these findings and the study of Pesole et al. (1991) could relate to the number of taxa examined and the methods of analysis chosen.

The $\mathrm{COB}$ and $\mathrm{COII}$ gene phylogenies also revealed somewhat different relationships among several taxa, and the differences depended upon the gene, character weighting scheme, and method of analysis chosen (Fig. 1 and Table 2). For example, the $\mathrm{COB}$ gene did not support the monophyly of the Artiodactyla family Cervidae (represented by Dama and Odocoileus), whereas the COII gene (represented by Cervus and Odocoileus) did. Most analyses (equal weighting, transversion only, and neighbor joining) of the COB gene failed to support monophyly of Primates, while the COII gene consistently supported monophyly. The COB gene supported the monophyly of the rodent suborder Hystricognathi (represented by Cavia and Hystrix) and the COII gene (represented by Cavia and Georychus) did not. A total evidence approach also was used to evaluate phylogenetic relationships. In this approach both genes were combined, using the taxa held in common, in an effort to use an unpartitioned set of synapomorphies (Kluge 1989; Eernisse and Kluge 1993). The overall results from this analysis were similar to those seen for the two genes analyzed separately, with neither gene having a stronger influence over the other (Table 2). However, unlike the two genes analyzed separately, the monophyly of the artiodactyl/cetacean clade (most analyses), rodent superorder Hystricognathi, and order Primates was supported. The monophyly of Cervidae was not supported. Again, 
Table 2. Phylogenetic relationships derived from either neighbor joining (NJ) using Kimura (1980) corrected distances or maximum parsimony (MP) using total substitutions with equal weighting (equal), transversions only (TV), and differential weighting (unequal) at each codon position

\begin{tabular}{|c|c|c|c|c|c|c|c|c|c|c|c|}
\hline \multirow[b]{2}{*}{ Phylogenetic conclusions ${ }^{\mathrm{a}}$} & \multicolumn{2}{|c|}{ MP equal } & \multicolumn{2}{|c|}{ MP TV only } & \multicolumn{2}{|c|}{ MP unequal } & \multicolumn{3}{|c|}{ MP total ${ }^{b}$} & \multicolumn{2}{|c|}{$\mathrm{NJ}$} \\
\hline & COII & $\mathrm{COB}$ & COII & $\mathrm{COB}$ & COII & $\mathrm{COB}$ & Equal & TV & Unequal & COII & $\mathrm{COB}$ \\
\hline Primate monophyly & + & - & + & - & + & + & + & + & + & + & - \\
\hline Rodent monophyly & - & - & - & - & - & - & - & - & - & - & - \\
\hline Hystricognathi & - & + & - & + & - & + & + & + & + & - & + \\
\hline Sciurognathi & - & - & - & - & - & - & - & - & - & - & - \\
\hline Muridae & + & + & + & + & + & + & + & + & + & + & + \\
\hline Geomyidae & + & + & + & + & + & + & + & + & + & + & + \\
\hline Artiodactyl monophyly & - & - & - & - & - & - & - & - & - & - & - \\
\hline Bovidae & + & + & + & + & + & + & + & + & + & - & + \\
\hline Cervidae & + & - & + & - & + & - & $?$ & - & - & + & - \\
\hline Sus Divergent & + & + & + & + & + & + & + & + & + & + & + \\
\hline \multicolumn{12}{|l|}{ Cetacean sister group } \\
\hline Ruminants only & + & - & + & - & + & - & $?$ & + & + & + & - \\
\hline Carnivores and artiodactyls & - & - & - & - & - & - & $?$ & - & - & - & - \\
\hline Sus & - & - & - & + & - & + & $?$ & - & - & - & + \\
\hline Carnivora & - & + & - & - & - & - & $?$ & - & - & - & - \\
\hline \multicolumn{12}{|l|}{ Carnivora sister group } \\
\hline Antilocapra & + & - & - & - & - & - & - & - & - & - & - \\
\hline Cetacea & - & + & - & - & - & - & $?$ & - & - & - & - \\
\hline Artiodactyla and Cetacea & + & - & $?$ & + & + & + & $?$ & + & + & - & + \\
\hline Sus & - & - & - & - & - & - & $?$ & - & - & + & - \\
\hline \multicolumn{12}{|l|}{ Lagomorpha sister group } \\
\hline Rodentia & $+1-$ & $+1-$ & $?$ & - & $+1-$ & - & $+1-$ & - & $+1-$ & - & - \\
\hline Primates & - & - & - & $+1-$ & - & + & - & + & - & - & $+1-$ \\
\hline
\end{tabular}

a The plus $(+)$ means relationship supported, minus $(-)$ indicates no support, $+l-$ implies a relationship with some but not all taxa in an order, and ? indicates that the relationship is unresolved

${ }^{\mathrm{b}}$ Each gene was analyzed separately and combined as total evidence (MP total)

the order Rodentia was found to be polyphyletic (four independently evolving lineages), with the geomyoid genera Geomys and Cratogeomys being the most divergent eutherian taxa (Fig. 1).

\section{Intraordinal Phylogenetic Comparisons}

Using the assumption that the order Rodentia and the Cetacea/Artiodactyla clade represent monophyletic groups, relationships among respective rodent and artiodactyl taxa were reexamined. Two approaches were used in this investigation. First, phylogenetic analyses on the same rodent and artiodactyl taxa, examined in the interordinal comparisons, were conducted using both maximum parsimony (an exhaustive search with either equal or unequal weighting) and neighbor joining. These analyses were done for each gene separately as well as the two genes combined. Second, patterns of variation in artiodactyl and rodent COB and COII genes were examined in reference to an independent phylogeny derived from an examination of other characters, including molecular and morphological (Figs. 2 and 3). For each codon position the retention index (Farris 1989), mean number of steps (average number of changes along each branch), and number of positions that were potentially informative in a cladistic sense (positions exhibiting at least two states with at least two taxa possessing each of the alternate states) were estimated by fitting characters on the reference phylogeny. The retention index was selected because it is insensitive to the number of taxa in a data set (Archie 1989) yet provides a measure of homoplasy. Although the COB and COII data sets for artiodactyls and rodents were not identical in terms of taxa examined, the taxa used in the comparisons spanned approximately the same range of divergence times (Table 3 , Figs. 2 and 3) and represented an overall increased number from those examined in the phylogenetic analyses. We realize that relationships involving some taxa in these phylogenies may be equivocal but the overall patterns observed for each order and gene were not influenced, to any large extent, by swapping individual branches in the tree topologies.

The COB and COII gene trees revealed problems similar to those seen in the interordinal comparisons (Fig. 4; see Table 1 for groups examined). In the case of rodents, the COII gene tree was less congruent with morphological data than that seen for COB. For example, the COB gene supported the monophyly of the suborder Hystricognathi (Cavia and Hystrix) and a sister-group relationship between the Sciurus and the Geomys/Cratogeomys clade (Fig. 4A). Both of these results are congruent with most ideas based on morphology. The COII gene tree did 
A

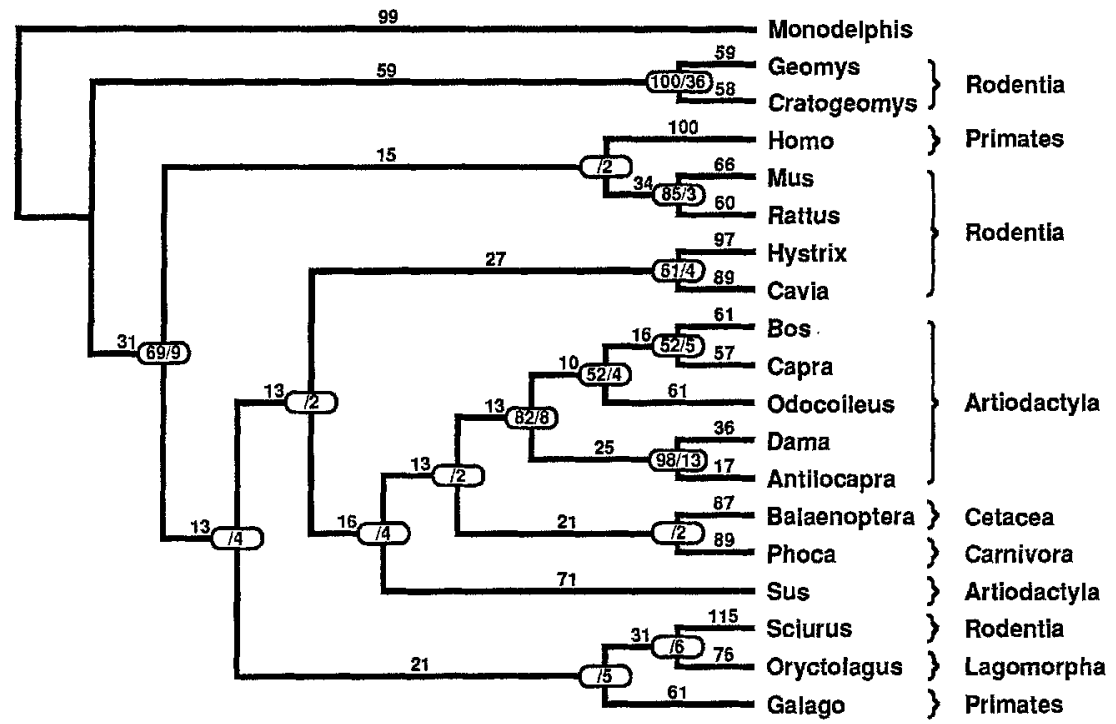

B

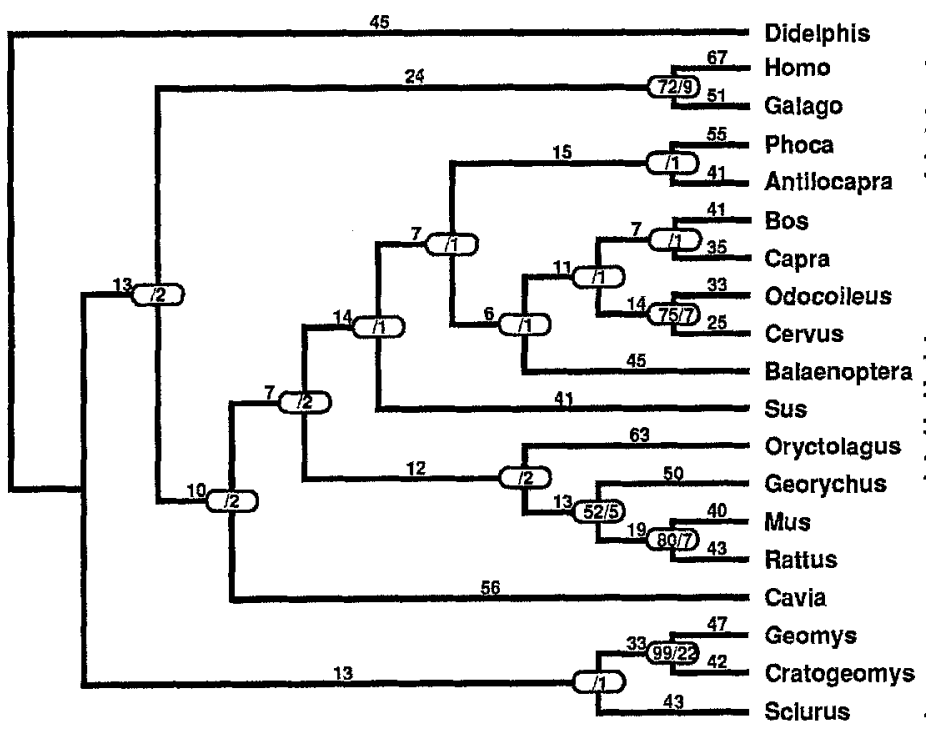

Fig. 1. Phylogenetic relationships among eutherian mammals based on maximum parsimony (A) of the $\mathrm{COB}$ gene (length $=1,540$, retention index 0.311) and (B) COII gene (length $=2,557$, retention index $=0.322$ ). Both trees were derived using equal weighting of total substitutions. Trees were constructed using 100 replications of the heuristic tree-bisection-reconnection search in PAUP, with the addition of taxa randomized. Inferred nucleotide changes are shown along each branch, and bootstrap values $50 \%$ or greater (derived from 100 replicates) are enclosed in circles with the Bremer support indices separated from these values by a diagonal line (n). not support either of these results, even when maximum parsimony with unequal character weighting was used (Fig. 4C). Neighbor-joining (not shown) also did not alter these results. The total evidence analysis for rodents was identical to the $\mathrm{COB}$ gene tree, and none of the analyses including the total evidence tree supported a monophyletic Sciurognathi (Fig. 4E). While the COII gene tree provided less resolution among the rodents, the $\mathrm{COB}$ gene tree provided less resolution for relationships among artiodactyls and cetaceans. The monophyly of Cervidae was not supported by the $\mathrm{COB}$ gene, and the placement of cetaceans relative to ruminants was unresolved (Fig. 4B). Both the total evidence and COII gene trees, however, favored a monophyletic Cervidae and a sister-group relationship between Cetacea and ruminants, with Sus being basal (Fig. 4D and F).

The level of homoplasy for both the COII and COB genes differed with respect to codon position and the taxa examined (Table 4). Rodents showed a higher level of homoplasy at the third position of the COII gene than that seen for artiodactyls, as well as an overall higher number of phylogenetically informative sites at the second position. Both orders showed a low retention index at the first position in COII. Artiodactyls showed a higher level of homoplasy at all positions in the $\mathrm{COB}$ gene than seen with rodents, especially at the first and second codon positions. The pattern revealed by artiodactyls and rodents did not change when the topologies in Figs. 2 and 3 were modified by rearranging individual lineages. This suggests that minor modifications of the accepted phylogeny do not alter the level of homoplasy seen for each gene tree relative to the presumed species trees. There are at least two explanations for these results, and they are not mutually exclusive. First, some of the differences in overall homoplasy observed between rodents and artiodactyls may be the result of differences 
A

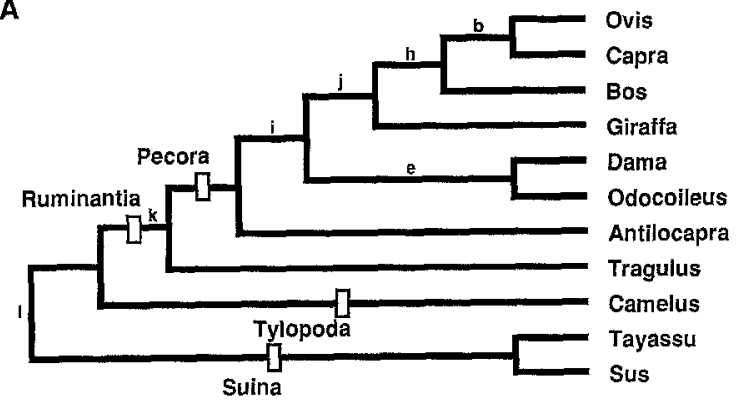

B

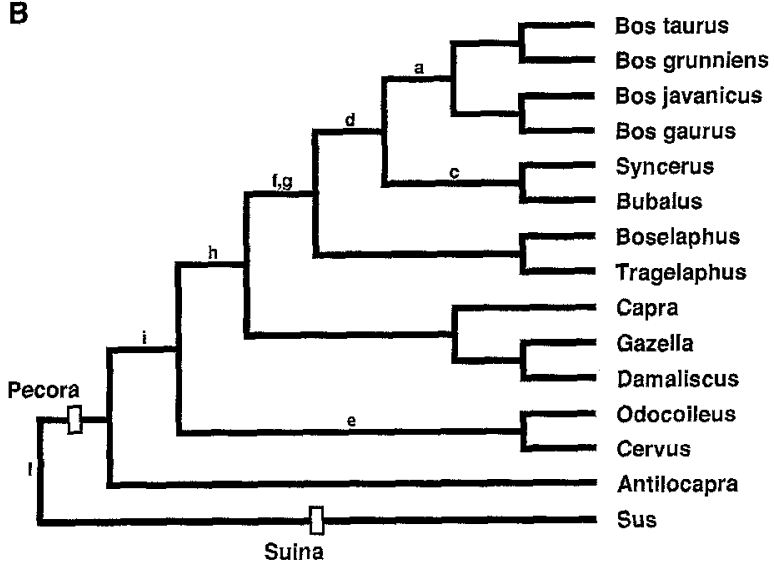

Fig. 2. Reference phylogenies for artiodactyls used to evaluate homoplasy in the (A) COB and (B) COIl genes. These phylogenies are based on several molecular and morphological studies including Janis and Scott (1987), Kraus and Miyamoto (1991), Allard et al. (1992), Gentry (1992), and Miyamoto et al. (1993, 1994). The letters $(a-l)$ on branches refer to the divergence dates shown in Table 3.

in the average divergence time separating taxa used in each phylogeny. In this case closely related taxa would show less homoplasy than more divergent taxa, especially with respect to the degree of saturation effects at third position and the overall amount of change at the first two positions. This cannot totally explain the observations because the patterns of change at the three codon positions for both $\mathrm{COB}$ and COII differ within orders. Second, the different patterns of homoplasy may be the result of different levels of selective constraints on the artiodactyl and rodent COII and COB genes. This partially explains differences between genes within orders. The phylogenetic differences observed for the two genes may be the net result of the overall patterns of homoplasy and number of informative characters at each codon position seen for rodent and artiodactyl COB and COII gene evolution.

\section{Processes of Molecular Evolution}

Transition/Transversion Ratios

A bias toward transitions over transversions, especially at lower levels of divergence, has been observed for mammalian mtDNA (Brown et al. 1982; Aquadro et al. 1984). Nevertheless, as indicated in a recent compar-
A

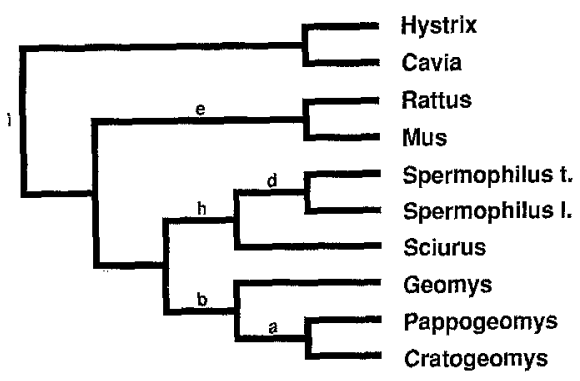

B

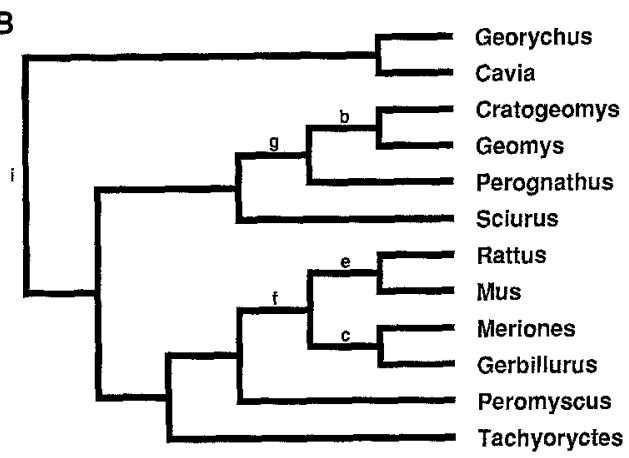

Fig. 3. Reference phylogenies for rodents used to evaluate homoplasy in the (A) COB and (B) COII genes. These phylogenies are based on current ideas of rodent relationships. (See references in Carleton and Musser 1984; Luckett and Hartenberger 1985; Catzeflis et al. 1992,1993 .) The letters $(a-i)$ on branches refer to the divergence dates in Table 3.

ison of the 12S rRNA gene in primates, rodents, and artiodactyls, the transition/transversion ratio relative to genetic divergence can vary among orders (Allard and Honeycutt 1992). A comparison of transition/transversion ratios relative to Jukes and Cantor (1969) distances between pairs of taxa revealed differences among rodent and artiodactyl COII and $\mathrm{COB}$ genes. At similar levels of $\mathrm{COB}$ gene divergence, rodents showed a higher transition/transversion ratio than that seen in artiodactyls, whereas artiodactyls revealed a higher ratio with the COII gene. The ratio stabilized in both orders at approximately $20 \%$ to $30 \%$ divergence for $\mathrm{COB}$ gene and $20 \%$ divergence for the COII gene. The cause of the observed taxonomic differences in transition/transversion ratios for these two genes is unknown. Either different mutation biases exist in regions under different structural constraint or a highly biased substitution process, in part due to selective constraints on the molecule, may be partially responsible (Allard and Honeycutt 1992). The evaluation of homoplasy found for each gene relative to an accepted phylogeny of rodents and artiodactyls (Table 4) did reveal substitution differences among the three codon positions, and these differences are suggestive of variation in selective constraint.

\section{Tests for Rate Heterogeneity}

Rate heterogeneity in terms of nucleotide substitutions and amino acid replacements has been found for both nuclear and mitochondrial genes in mammals, sug- 
Table 3. Approximate divergence dates for rodents and artiodactyls

\begin{tabular}{llll}
\hline Comparison & Node $^{\mathrm{a}}$ & Divergence time (Myr) ${ }^{b}$ & Reference \\
\hline Rodentia & & & \\
Pappogeomys/Cratogeomys & $\mathrm{a}$ & $4(3-5)$ & Russell (1968b) \\
Geomys/Cratogeomys & $\mathrm{b}$ & $6(5-7)$ & Russell (1968a) \\
Gerbillurus/Meriones & $\mathrm{c}$ & 6 & Catzeflis et al. (1993) \\
Spermophilus t./S. l. & $\mathrm{d}$ & $10(9-12)$ & Black (1963) \\
Mus/Rattus & $\mathrm{e}$ & $11(10-12)$ & Catzeflis et al. (1992) \\
Gerbillinae/Murinae & $\mathrm{f}$ & $15-23$ & Catzeflis et al. (1992) \\
Geomys/Perognathus & $\mathrm{g}$ & 30 & Green and Bjork (1980) \\
Sciurus/Spermophilus & $\mathrm{h}$ & 30 & Black (1963) \\
Hystricognathi/Sciurognathi & $\mathrm{i}$ & 55 & Flynn et al. (1986) \\
Artiodactyla & & & \\
Bos taurus/Bos gaurus & $\mathrm{a}$ & 2 & Pilgrim (1947) \\
Capra/Ovis & $\mathrm{b}$ & $5(4-10)$ & Savage and Russell (1983) \\
Bubalus/Syncerus & $\mathrm{c}$ & 5 & Savage and Russell (1983) \\
Bos/Syncerus & $\mathrm{d}$ & 10 & Savage and Russell (1983) \\
Odocoileus/Cervus \& Dama & $\mathrm{e}$ & $10.5(9-12)$ & Miyamoto et al. (1990) \\
Bos/Boselaphus & $\mathrm{f}$ & 15 & Savage and Russell (1983) \\
Bos/Tragelaphus & $\mathrm{g}$ & 20 & Savage and Russell (1983) \\
Bos/Capra & $\mathrm{h}$ & 20 & Savage and Russell (1983) \\
Bovidae/Cervidae & $\mathrm{i}$ & 25 & Savage and Russell (1983) \\
Bovidae/Giraffidae & $\mathrm{j}$ & 25 & Savage and Russell (1983) \\
Pecorans/Tragulina & $\mathrm{k}$ & 45 & Kraus and Miyamoto (1991) \\
Ruminantia/Sus & 1 & $55(50-65)$ & Savage and Russell (1983) \\
\hline
\end{tabular}

${ }^{\text {a }}$ Nodes are identified on Figs. 2 and 3

${ }^{\mathrm{b}}$ Date not in parentheses used for plots in Fig. 5

gesting a lack of a global molecular clock for mammals (Wu and Li 1985; Britten 1986; Li et al. 1987; Bulmer et al. 1991; Holmes 1991; $\mathrm{Ma}$ et al. 1993; Martin and Palumbi 1993; Adkins and Honeycutt 1994; Irwin and Arnason 1994). As suggested earlier, excessive rate heterogeneity may influence phylogenetic results. The new sequence data presented here allow for a more extensive examination of rate heterogeneity within and between several orders of mammals, especially the orders Rodentia and Artiodactyla. Two approaches were used to examine rate differences for the $\mathrm{COII}$ and $\mathrm{COB}$ genes. First, both interordinal and intraordinal pairwise comparisons were made, using either total substitutions or third position transversions, and deviations from rate homogeneity were tested using the relative rate test of Mindell and Honeycutt (1990). Second, the rate of nonsynonymous and synonymous substitutions for both artiodactyl and rodent $\mathrm{COB}$ and $\mathrm{COII}$ genes was determined in reference to known divergence times.

The relative rate tests revealed several cases of rate heterogeneity, especially with respect to total substitutions (Table 5). First, primates had a faster rate of total substitutions in the COII gene relative to all orders, and the primate $\mathrm{COB}$ gene was faster relative to muroid rodents (Mus) and carnivores (Phoca). Within the order Primates the rate of total substitutions for both the COII and COB genes was higher in anthropoid primates (represented by Homo) in comparison to prosimian primates (represented by Galago). Although there is little nucleotide sequence data for the primate $\mathrm{COB}$ gene, these results suggest that the overall pattern of primate $\mathrm{COB}$ gene evolution may be similar to that seen for primate COII. As suggested in previous studies, the rate increase in the COII gene observed in primates may relate to an increased rate in the nuclear cytochrome $c$ gene of primates, and it now appears that the $\mathrm{COB}$ gene, which also interacts with cytochrome $c$, demonstrates a somewhat similar pattern to COII (Ma et al. 1993; Adkins and Honeycutt 1994; unpublished data). Second, within artiodactyls the genus Bos (cow) revealed a slower rate of total substitutions than that seen in several other lineages, and unlike the correlation between body size and rate of COB evolution observed by Martin and Palumbi (1993), the Bos rate was slower than that of the whale. In addition, both the COII and $\mathrm{COB}$ genes revealed a slower rate of total nucleotide substitutions in the artiodactyl genus Antilocapra relative to cervids. Finally, most studies of rodent nuclear gene evolution have suggested rate homogeneity among rodent lineages (Bulmer et al. 1991; O'hUigin and Li 1992). Nevertheless, both the COII and $\mathrm{COB}$ genes revealed a faster rate of total substitutions in geomyoid rodents, represented by Geomys and Cratogeomys, than that seen for muroid rodents, Mus and Rattus, confirming the observations of DeWalt et al. (1993) based on $\mathrm{COB}$.

In addition to the relative rate tests, substitution rate differences for the COB and COII genes were examined by plotting the number of substitutions at both synonymous and nonsynonymous sites over a range of divergence times for pairs of artiodactyl and rodent taxa. Both the $\mathrm{COB}$ and $\mathrm{COII}$ genes of rodents in comparison to artiodactyls showed a higher rate of substitution at syn- 
A
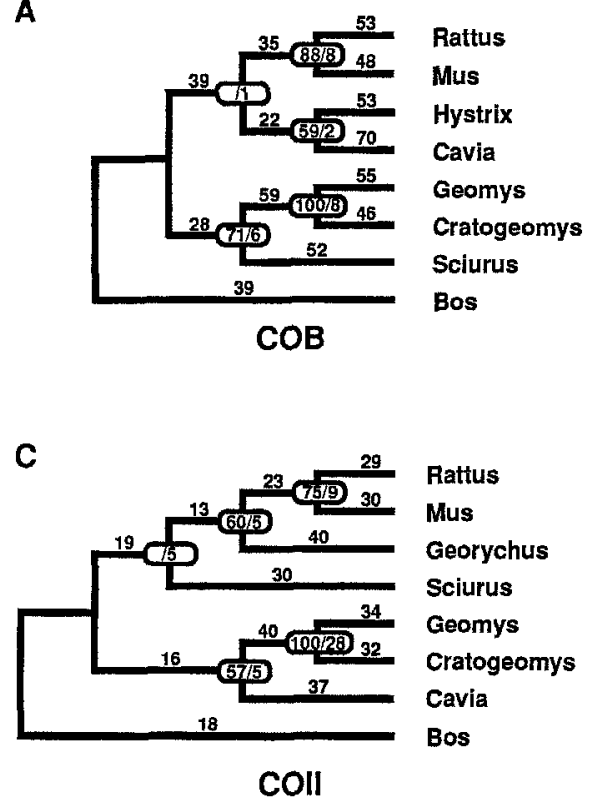

E

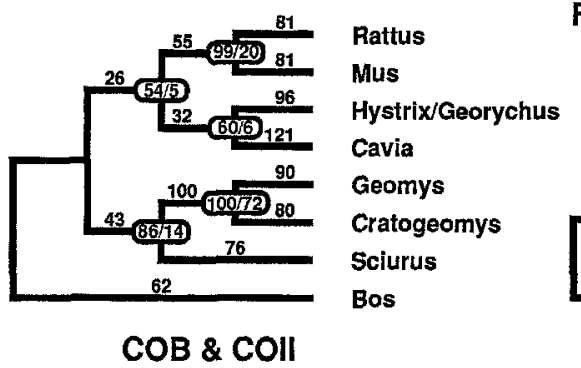

Fig. 4. Maximum parsimony trees derived using the exhaustive search option in PAUP. Trees were constructed using total substitutions and equal weighting for the COB genes of (A) rodents (length $=1,005$, retention index $=0.379$ ) and $(\mathbf{B})$ artiodactyls (length $=622$, retention index $=0.351$ ) and the COII genes of $(C)$ rodents (length $=590$, retention index $=0.378$ ) and $(D)$ artiodactyls (length $=382$, retention index $=0.314$ ). Both genes were combined to construct a total evidence

D
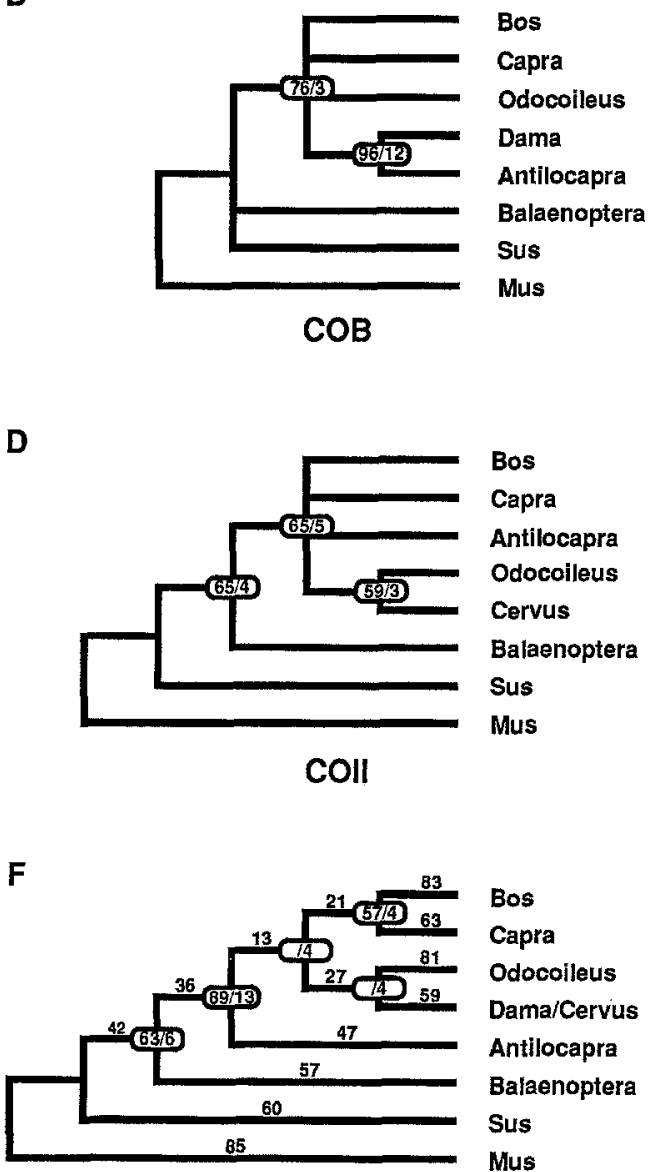

COB \& COII

tree for $(\mathbf{E})$ rodents (length $=1,600$, retention index $=0.374$ ) and $(\mathbf{F})$ artiodactyls (length $=1,020$, retention index $=0.313$ ). Numbers along branches represent inferred nucleotide changes. Trees $\mathbf{B}$ and $\mathbf{D}$ represent strict consensus trees derived from three and four equally parsimonious trees, respectively. Bootstrap values $50 \%$ or greater (based on 100 replicates) are encircled and separated from the Bremer support indices by a diagonal (/) line.

Table 4. Homoplasy at different codon positions for artiodactyl and rodent COII and COB genes in reference to the phylogenies in Figs. 2 and 3

\begin{tabular}{|c|c|c|c|c|c|c|c|c|c|}
\hline \multirow[b]{2}{*}{ Comparison } & \multicolumn{3}{|c|}{ First position } & \multicolumn{3}{|c|}{ Second position } & \multicolumn{3}{|c|}{ Third position } \\
\hline & $\mathrm{RI}^{\mathrm{a}}$ & $\begin{array}{l}\text { Informative } \\
\text { positions }^{b}\end{array}$ & $\begin{array}{l}\text { Mean } \\
\text { no. steps }\end{array}$ & $\mathrm{RI}^{\mathrm{a}}$ & $\begin{array}{l}\text { Informative } \\
\text { positions }^{\text {b }}\end{array}$ & $\begin{array}{l}\text { Mean } \\
\text { no. steps }\end{array}$ & $\mathrm{RI}^{\mathrm{a}}$ & $\begin{array}{l}\text { Informative } \\
\text { positions }^{\mathrm{b}}\end{array}$ & $\begin{array}{l}\text { Mean } \\
\text { no. steps }\end{array}$ \\
\hline \multicolumn{10}{|l|}{ COII } \\
\hline Artiodactyla & 0.30 & 31 & 3.32 & - & 0 & - & 0.41 & 167 & 2.76 \\
\hline Rodentia & 0.35 & 63 & 3.01 & 0.67 & 15 & 2.33 & 0.23 & 190 & 4.09 \\
\hline \multicolumn{10}{|l|}{$\mathrm{COB}$} \\
\hline Artiodactyla & 0.33 & 57 & 2.74 & 0.31 & 18 & 2.39 & 0.28 & 248 & 3.29 \\
\hline Rodentia & 0.56 & 104 & 2.53 & 0.78 & 43 & 1.65 & 0.34 & 284 & 3.34 \\
\hline
\end{tabular}

${ }^{a}$ Retention index

${ }^{b}$ Only positions informative in a cladistic sense are considered

onymous and nonsynonymous sites (Fig. 5). This result is similar to that found for synonymous and nonsynonymous rates in the nuclear genes of rodents and artiodactyls ( $\mathrm{Li}$ et al. 1987; Bulmer et al. 1991). In the case of the COII gene, synonymous sites were saturated in rodents, and this observation is consistent with the high levels of homoplasy at the third position of the COII gene found in rodents relative to artiodactyls (Table 4). 
Table 5. Results of relative rate tests

\begin{tabular}{|c|c|c|c|c|}
\hline \multirow[b]{2}{*}{ Comparison } & \multicolumn{2}{|c|}{$\begin{array}{c}\text { Total } \\
\text { substitutions }\end{array}$} & \multicolumn{2}{|c|}{$\begin{array}{l}\text { Third position } \\
\text { transversions }\end{array}$} \\
\hline & COII & $\mathrm{COB}$ & COII & $\mathrm{COB}$ \\
\hline \multicolumn{5}{|l|}{ Rodentia $^{b}$} \\
\hline Mus/Geomys & $0.0176^{*}$ & $0.0546^{*}$ & 0.4495 & 0.1041 \\
\hline \multicolumn{5}{|l|}{ Artiodactyla $^{\circ}$} \\
\hline Bos/Balaenoptera & 0.4668 & $0.0469 *$ & 0.1802 & 0.3285 \\
\hline Bos/Tragulus & - & $0.0503 *$ & - & 0.4050 \\
\hline Bos/Camelus & - & $0.0049 *$ & - & $0.0251 *$ \\
\hline Antilocapra/Dama & - & $0.0363^{*}$ & - & 0.5000 \\
\hline Antilocapra/Cervus & $0.0535 \%$ & - & 0.4159 & - \\
\hline \multicolumn{5}{|l|}{ Primates $^{\mathrm{d}}$} \\
\hline Homo/Galago & $0.0310^{*}$ & $0.0000^{*}$ & 0.3518 & 0.1841 \\
\hline \multicolumn{5}{|l|}{ Interordinal $^{\mathrm{e}}$} \\
\hline Homo/Bos & $0.0006 *$ & 0.0992 & 0.3101 & 0.5000 \\
\hline Homo/Mus & $0.0001 *$ & $0.0005^{*}$ & 0.1108 & 0.2376 \\
\hline Homo/Phoca & $0.0018^{*}$ & $0.0419 *$ & $0.0103^{*}$ & 0.4234 \\
\hline Homo/Lagomorpha & $0.0033 *$ & 0.0686 & $0.0556^{*}$ & 0.2773 \\
\hline Galago/Mus & $0.0095 *$ & 0.0624 & 0.3974 & 0.2810 \\
\hline Galago/Bos & $0.0323^{*}$ & 0.3406 & 0.1528 & 0.4602 \\
\hline Lagomorpha/Mus & 0.1649 & $0.0312 *$ & 0.4478 & 0.0878 \\
\hline Lagomorpha/Geomys & 0.4722 & 0.5000 & 0.5531 & $0.0335 *$ \\
\hline Phoca/Bos & 0.4063 & 0.3514 & $0.0178^{*}$ & 0.3718 \\
\hline Phoca/Mus & 0.2262 & $0.0540^{*}$ & 0.1358 & 0.3439 \\
\hline
\end{tabular}

${ }^{a}$ Probability values obtained using the binomial distribution of Mindell and Honeycutt (1990), with asterisk (*) indicating significant or nearly significant values at $\mathrm{p}=.05$.

${ }^{b}$ Cavia used as outgroup

${ }^{c}$ Phoca used as outgroup

${ }^{\mathrm{d}} \mathrm{Bos}$ used as outgroup

${ }^{\mathrm{e}}$ Didelphis or Monodelphis used as outgroup

The COB gene of both rodents and artiodactyls demonstrated a higher rate of nonsynonymous substitutions than the COII gene, and as can be seen in Table 4, the overall number of informative sites at the first, second, and third positions is higher in the $\mathrm{COB}$ gene of both rodents and artiodactyls.

\section{Base Composition and Codon Usage}

Base composition at each of three codon positions was calculated from the nucleotide sequence data (all rodents and artiodactyls in Table 1), and the index of compositional bias (Irwin et al. 1991), which measures deviation from an equal (25\%) frequency of each nucleotide, was estimated. In general, both the rodent and artiodactyl COII and $\mathrm{COB}$ genes showed a similar pattern, with base composition bias being greater at the third and lowest at the first codon positions (Table 6). At the second position of both the COB and COII genes, there is a bias toward thymine at the expense of guanine, and in the COII gene adenine is somewhat higher than cytosine, with the opposite observed for the COB gene. The COB gene shows an overall higher level of composition bias at the third codon position, and in both genes the greatest asymmetry is between adenine (high) and guanine (low). In addition, the frequency of cytosine at the
A
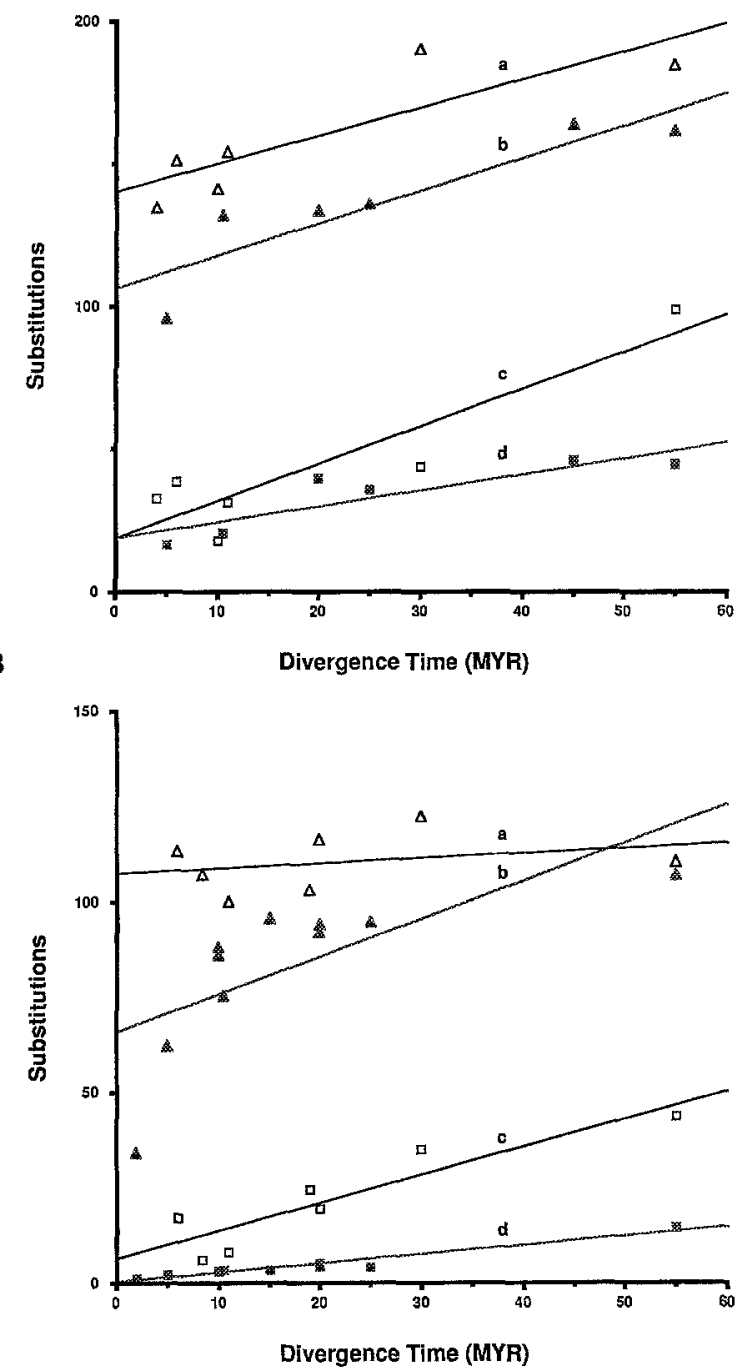

Fig. 5. Plots of nucleotide substitutions for the (A) $\mathrm{COB}$ and (B) COII. Substitutions at both $(\mathbf{a}, \mathbf{b})$ synonymous and $(\mathbf{c}, \mathbf{d})$ nonsynonymous sites for pairwise comparisons were plotted relative to divergence time. Each point represents the average of all possible pairwise comparisons, with the divergence times for these comparisons shown in Table 3. Open and closed triangles represent synonymous substitutions in rodents and artiodactyls, respectively. Open and closed squares represent nonsynonymous substitutions for rodents and artiodactyls, respectively.

third position of COII is somewhat lower than that observed for $\mathrm{COB}$. The overall level of heterogeneity in base composition was higher at the third position and lowest at second position, as can be seen by the increased level of coefficients of variation associated with estimates of base frequencies. The increased heterogeneity has a taxonomic basis in that individual lineages and groups of taxa differ in base composition, with rodents demonstrating a greater amount of heterogeneity. These increased levels of heterogeneity, as a result of taxonomic variation at the third codon position in the $\mathrm{COB}$ and COII genes, are similar to patterns reported for primate COII (Adkins and Honeycutt 1994) and ungulate COB (Irwin et al. 1991), and one would expect to see this 
Table 6. Base composition at first, second, and third codon positions

\begin{tabular}{|c|c|c|c|c|c|c|c|c|c|c|c|c|}
\hline \multirow[b]{2}{*}{ Comparison $^{a}$} & \multicolumn{4}{|c|}{ First codon position } & \multicolumn{4}{|c|}{ Second codon position } & \multicolumn{4}{|c|}{ Third codon position } \\
\hline & A & $\mathrm{C}$ & $\mathrm{G}$ & $\mathrm{T}$ & A & $\mathrm{C}$ & $\mathrm{G}$ & $\mathrm{T}$ & A & $\mathrm{C}$ & $\mathrm{G}$ & $\mathbf{T}$ \\
\hline \multicolumn{13}{|l|}{$\mathrm{COB}$} \\
\hline Artiodactyla ${ }^{b}$ & 0.295 & 0.258 & 0.220 & 0.218 & 0.200 & 0.241 & 0.135 & 0.416 & 0.434 & 0.358 & 0.043 & 0.157 \\
\hline $\mathrm{CV}^{\mathrm{c}}$ & 4.60 & 4.91 & 4.27 & 5.45 & 1.82 & 2.99 & 1.95 & 2.01 & 4.77 & 6.91 & 37.32 & 19.08 \\
\hline Index ${ }^{\mathrm{d}}$ & \multicolumn{4}{|c|}{$(0.077)$} & \multicolumn{4}{|c|}{$(0.227)$} & \multicolumn{4}{|c|}{$(0.395)$} \\
\hline Rodentia & 0.280 & 0.248 & 0.215 & 0.252 & 0.204 & 0.239 & 0.139 & 0.415 & 0.422 & 0.306 & 0.032 & 0.237 \\
\hline $\mathrm{CV}$ & 3.35 & 4.09 & 2.91 & 3.47 & 2.30 & 2.68 & 3.16 & 2.40 & 11.05 & 12.46 & 37.02 & 18.49 \\
\hline Index & \multicolumn{4}{|c|}{$(0.046)$} & \multicolumn{4}{|c|}{$(0.222)$} & \multicolumn{4}{|c|}{$(0.321)$} \\
\hline \multicolumn{13}{|l|}{ COII } \\
\hline Artiodactyla & 0.296 & 0.249 & 0.235 & 0.220 & 0.267 & 0.242 & 0.114 & 0.377 & 0.468 & 0.234 & 0.085 & 0.213 \\
\hline $\mathrm{CV}$ & 2.16 & 3.96 & 2.41 & 5.04 & 0.59 & 1.05 & 1.01 & 0.50 & 4.25 & 13.02 & 26.65 & 14.87 \\
\hline Index & \multicolumn{4}{|c|}{$(0.061)$} & \multicolumn{4}{|c|}{ (0.192) } & \multicolumn{4}{|c|}{$(0.291)$} \\
\hline Rodentia & 0.298 & 0.237 & 0.244 & 0.220 & 0.269 & 0.239 & 0.114 & 0.378 & 0.443 & 0.247 & 0.050 & 0.260 \\
\hline $\mathrm{CV}$ & 3.26 & 7.34 & 4.15 & 6.85 & 1.93 & 3.68 & 2.39 & 1.53 & 7.58 & 20.49 & 51.66 & 13.86 \\
\hline Index & \multicolumn{4}{|c|}{$(0.064)$} & \multicolumn{4}{|c|}{$(0.196)$} & \multicolumn{4}{|c|}{$(0.271)$} \\
\hline
\end{tabular}

${ }^{a}$ All taxa listed in methods section were used

${ }^{b}$ Mean frequency for all taxa

${ }^{\mathrm{c}}$ Coefficient of variation

${ }^{d}$ Index of compositional bias (Irwin et al. 1991)

trend continue as more mammalian orders are examined in detail.

As expected, the frequency of codon usage among twofold and fourfold degenerate codons corresponded to the observed base composition bias seen at the third codon position (Table 7). For instance, codons with guanine at the third position of both the $\mathrm{COB}$ and COII genes were used less frequently than adenine. In addition to the similarities in codon usage observed for rodent and artiodactyl $\mathrm{COB}$ and $\mathrm{COII}$, the two orders differed with respect to codon usage at several amino acids. A nonrandom usage of synonymous codons has been noted for many organisms (Ikemura 1985; Sharp et al. 1988), and several models have considered genetic drift, selection, and fluctuating mutation bias as explanations for this observation ( $\mathrm{Li} \mathrm{1987;} \mathrm{Shields} \mathrm{1990).} \mathrm{In} \mathrm{the} \mathrm{case} \mathrm{of} \mathrm{the}$ mammalian $\mathrm{COB}$ and $\mathrm{COII}$ genes, it is unclear what processes are involved. There appears to be no general pattern across all taxa for a particular gene, and therefore, an argument invoking selection would seem unlikely.

\section{Conclusions}

The detail examination of $\mathrm{COII}$ and $\mathrm{COB}$ gene variation in mammals reveals several examples of incongruence involving different gene trees and comparisons of gene trees with accepted species trees. If one assumes that a single "true phylogeny" exists and that mitochondrial genes are linked and inherited as a single locus, how can the incongruence seen between the gene phylogenies of $\mathrm{COB}$ and $\mathrm{COII}$ as well as among phylogenies derived from independent characters be explained? In some cases, such as that seen for the placement of cetaceans as sister to ruminant artiodactyls, there may be strong molecular evidence with little morphological evidence contradicting the gene tree results. In other cases (e.g., the monophyly of rodents), an explanation for such differences may require a detailed examination of both molecular and morphological character evolution. The $\mathrm{COB}$ and $\mathrm{COII}$ gene data provide evidence in support of this idea. For example, heterogeneity in both the overall rate of nucleotide substitutions and the types of substitutions allowed (transition/transversion ratios, base composition, codon usage) has been demonstrated in the detailed comparisons of both genes and orders. This heterogeneity probably explains many of the differences in homoplasy associated with the first, second, and third codon positions seen for the two genes (Table 4), and in the case of mammalian ordinal relationships, a consideration of total evidence did not resolve some discrepancies. As has been suggested by several authors (Felsenstein 1978; Holmes 1991; Irwin et al. 1991; Sidow and Wilson 1991; Honeycutt and Adkins 1993; Miyamoto et al. 1994), rate heterogeneity and differences in the pattern of nucleotide substitutions between taxa and genes may affect phylogeny reconstruction, especially among divergent taxa. If the order Rodentia is monophyletic, then this heterogeneity may well account for the distribution of several divergent rodent lineages throughout the eutherian mammal phylogeny. Finally, it is clear from this study that a detailed phylogenetic examination, using a larger number of taxa within orders of mammals and several orthologous genes, has the potential to provide insight into both the relationships among eutherian mammals and the evolution of mammalian genes. Nevertheless, the overall 
Table 7. Codon usage for COII and $\mathrm{COB}$ genes of artiodactyls and rodents, reflecting the frequency of all possible bases at the third codon position $^{\mathrm{a}}$

\begin{tabular}{|c|c|c|c|c|c|c|c|c|c|c|c|c|c|c|c|c|}
\hline \multirow{2}{*}{$\begin{array}{l}\text { Amino } \\
\text { acid }\end{array}$} & \multicolumn{4}{|c|}{ Rodent COII } & \multicolumn{4}{|c|}{ Artiodactyla COII } & \multicolumn{4}{|c|}{ Rodent COB } & \multicolumn{4}{|c|}{ Artiodactyla COB } \\
\hline & A & $\mathrm{G}$ & $\mathrm{C}$ & $\mathrm{T}$ & A & $\mathrm{G}$ & $\mathrm{C}$ & $\mathrm{T}$ & $\mathrm{A}$ & $\mathrm{G}$ & $\mathrm{C}$ & $\mathrm{T}$ & A & G & $\mathrm{C}$ & $\mathrm{T}$ \\
\hline Phe & & & 0.52 & 0.48 & & & 0.53 & 0.47 & & & 0.58 & 0.42 & & & 0.68 & 0.32 \\
\hline Leu & 0.67 & 0.07 & 0.07 & 0.19 & 0.69 & 0.12 & 0.05 & 0.14 & 0.69 & 0.04 & 0.13 & 0.14 & 0.63 & 0.07 & 0.22 & 0.08 \\
\hline Ile & & & 0.40 & 0.60 & & & 0.43 & 0.57 & & & 0.49 & 0.51 & & & 0.62 & 0.38 \\
\hline Met & 0.83 & 0.17 & & & 0.77 & 0.23 & & & 0.87 & 0.13 & & & 0.80 & 0.20 & & \\
\hline Val & 0.48 & 0.07 & 0.19 & 0.26 & 0.43 & 0.08 & 0.26 & 0.23 & 0.50 & 0.03 & 0.26 & 0.21 & 0.49 & 0.07 & 0.33 & 0.11 \\
\hline Ser & 0.54 & 0.03 & 0.22 & 0.21 & 0.50 & 0.04 & 0.21 & 0.25 & 0.58 & 0.02 & 0.20 & 0.20 & 0.53 & 0.03 & 0.28 & 0.16 \\
\hline Pro & 0.53 & 0.02 & 0.18 & 0.27 & 0.58 & 0.05 & 0.23 & 0.14 & 0.56 & 0.02 & 0.23 & 0.19 & 0.64 & 0.03 & 0.23 & 0.10 \\
\hline Thr & 0.54 & 0.02 & 0.19 & 0.25 & 0.62 & 0.08 & 0.19 & 0.11 & 0.50 & 0.03 & 0.26 & 0.21 & 0.62 & 0.02 & 0.25 & 0.11 \\
\hline $\mathrm{Ala}$ & 0.25 & 0.01 & 0.32 & 0.42 & 0.49 & 0.09 & 0.18 & 0.24 & 0.36 & 0.02 & 0.38 & 0.24 & 0.57 & 0.02 & 0.28 & 0.13 \\
\hline Tyr & & & 0.49 & 0.51 & & & 0.48 & 0.52 & & & 0.55 & 0.45 & & & 0.62 & 0.38 \\
\hline His & & & 0.61 & 0.39 & & & 0.62 & 0.38 & & & 0.61 & 0.39 & & & 0.75 & 0.25 \\
\hline Gln & 0.92 & 0.08 & & & 0.88 & 0.12 & & & 0.91 & 0.09 & & & 0.84 & 0.16 & & \\
\hline Asn & & & 0.55 & 0.45 & & & 0.64 & 0.36 & & & 0.65 & 0.35 & & & 0.76 & 0.24 \\
\hline Lys & 0.95 & 0.05 & & & 0.75 & 0.25 & & & 0.94 & 0.06 & & & 0.88 & 0.12 & & \\
\hline Asp & & & 0.59 & 0.41 & & & 0.54 & 0.46 & & & 0.67 & 0.33 & & & 0.75 & 0.25 \\
\hline Glu & 0.86 & 0.14 & & & 0.79 & 0.21 & & & 0.83 & 0.17 & & & 0.92 & 0.08 & & \\
\hline Cys & & & 0.54 & 0.46 & & & 0.79 & 0.21 & & & 0.79 & 0.21 & & & 0.89 & 0.11 \\
\hline Trp & 0.91 & 0.09 & & & 0.93 & 0.07 & & & 0.97 & 0.03 & & & 0.97 & 0.03 & & \\
\hline $\mathrm{Arg}$ & 0.47 & 0.04 & 0.27 & 0.22 & 0.73 & 0.04 & 0.06 & 0.17 & 0.81 & 0.02 & 0.12 & 0.05 & 0.88 & 0.02 & 0.06 & 0.04 \\
\hline Ser & & & 0.80 & 0.20 & & & 0.81 & 0.19 & & & 0.70 & 0.30 & & & 0.76 & 0.24 \\
\hline Gly & 0.35 & 0.16 & 0.33 & 0.16 & 0.42 & 0.15 & 0.29 & 0.14 & 0.50 & 0.09 & 0.23 & 0.18 & 0.60 & 0.10 & 0.25 & 0.05 \\
\hline
\end{tabular}

a Termination codons are not included

model of gene evolution, in terms of rates and the distribution of substitutions allowed, may be more complex than previously anticipated.

Acknowledgments. We thank Robert Bradley and two anonymous reviewers for their comments and criticisms on an earlier draft of this manuscript. David Irwin and Ulfur Arnason provided us access to the rabbit cytochrome $b$ sequence and a draft of their submitted manuscript. Anne Yoder kindly provided us with the Galago crassicaudatus cytochrome $b$ sequence. We thank Duane Schlitter (Section of Mammals, Carneigie Museum), Robert J. Baker (The Museum, Texas Tech University), I.L. Rautenbach (Transvaal Museum, South Africa), and B.H. Erasmus (McGregor Provincial Museum, South Africa) for access to frozen tissues. Drs. Rautenbach and Erasmus also collaborated with R.L.H. on the collections of African rodents. This research was supported by grants from the National Science Foundation to R.L.H. (BSR-8918445 and DEB-9208022). Part of the data analysis was carried out in the Center for Biosystematics and Biodiversity, a facility funded, in part, by the National Science Foundation under grant DIR8907006. This paper represents contribution 45 of the Center. The new nucleotide sequences reported in this paper have been submitted to GenBank under accession numbers U18815, U18816, and U18818U18838.

\section{References}

Adkins RM, Honeycutt RL (1991) Molecular phylogeny of the superorder Archonta. Proc Natl Acad Sci USA 88:10317-10321

Adkins RM, Honeycutt RL (1993) A molecular examination of archontan and chiropteran monophyly. In: MacPhee RDE (ed) Primates and their relatives in phylogenetic perspective. Plenum Press, New York, pp 227-249

Adkins RM, Honeycutt RL (1994) Evolution of the primate cytochrome $c$ oxidase II gene. J Mol Evol 38:215-231
Allard MW, Ellsworth DL, Honeycutt RL (1991a) The production of single-stranded DNA suitable for sequencing using the polymerase chain reaction. Biotechniques 10:24-26

Allard MW, Miyamoto MM, Honeycutt RL (1991b) Tests for rodent polyphyly. Nature 353:610-611

Allard MW, Honeycutt RL (1992) Nucleotide sequence variation in the mitochondrial $12 \mathrm{~S}$ rRNA gene and the phylogeny of African molerats (Rodentia: Bathyergidae). Mol Biol Evol 9:27-40

Allard MW, Miyamoto MM, Jarecki L, Kraus F, Tennant MR (1992) DNA systematics and evolution of the artiodactyl family Bovidae. Proc Natl Acad Sci USA 89:3972-3976

Anderson S, Bankier AT, Barrell BG, de Bruijn MHL, Coulson AR, Drouin J, Eperon IC, Nierlich DP, Ro BA, Sange F, Schreie PH, Smith AJH, Staden R, Young IG (1981) Sequence and organization of the human mitochondrial genome. Nature 290:457-465

Anderson S, De Bruijn MHL, Coulson AR, Eperon IC, Sanger F, Young IG (1982) Complete sequence of bovine mitochondrial DNA: conserved features of the mammalian mitochondrial genome. J Mol Biol 156:683-717

Aquadro CF, Kaplan N, Risko KJ (1984) An analysis of the dynamics of mammalian mitochondrial DNA sequence evolution. Mol Biol Evol 1:423-434

Archie JW (1989) Homoplasy excess ratios: new indices for measuring levels of homoplasy in phylogenetic systematics and a critique of the consistency index. Syst Zool 38:253-269

Arnason U, Gullberg A, Widegren B (1991) The complete nucleotide sequence of the mitochondrial DNA of the fin whale, Balaenoptera physalus. J Mol Evol 33:556-568

Arnason U, Johnsson E (1992) The complete mitochondrial DNA sequence of the harbor seal, Phoca vitulina. J Mol Evol 34:493-505

Bibb MJ, Van Etten RA, Wright CT, Walberg MW, Clayton DA (1981) Sequence and gene organization of mouse mitochondrial DNA. Cell 26:167-180

Black CC (1963) A review of the North American Tertiary Sciuridae. Bull Mus Comp Zool Harvard 130:109-248 
Bremer K (1988) The limits of amino-acid sequence data in angiosperm phylogenetic reconstruction. Evolution 42:795-803

Britten RJ (1986) Rates of DNA sequence evolution differ between taxonomic groups. Science 231:1393-1398

Brown WM (1980) Polymorphism in mitochondrial DNA of humans as revealed by restriction endonuclease analysis. Proc Natl Acad Sci USA 77:3605-3609

Brown WM, Prager EM, Wang A, Wilson AC (1982) Mitochondrial DNA sequences of primates: tempo and mode of evolution. J Mol Evol 18:225-239

Bulmer M, Wolfe KH, Sharp PM (1991) Synonymous nucleotide substitution rates in mammalian genes: implications for the molecular clock and the relationship of mammalian orders. Proc Natl Acad Sci USA 88:5974-5978

Carleton MD, Musser GG (1984) Muroid rodents. In: Anderson S, Jones JK (eds) Orders and families of recent mammals of the world. John Wiley \& Son, New York, pp 289-379

Catzeflis FM, Aguilar J-P, Jaeger J-J (1992) Muroid rodents: phylogeny and evolution. Tree 7:122-126

Catzeflis FM, Dickerman AW, Michaux J, Kirsch JAW (1993) DNA hybridization and rodent phylogeny. In: Szalay FS, Novacek MJ, McKenna MC (eds) Mammalian phylogeny. Springer-Verlag, New York, pp 159-172

DeWalt TS, Sudman PD, Hafner MS, Davis SK (1993) Phylogenetic relationships of pocket gophers (Cratogeomys and Pappogeomys) based on mitochondrial DNA cytochrome $b$ sequences. Mol Phyl Evol 2:193-204

Disotell TR, Honeycutt RL, Ruvolo M (1992) Mitochondrial DNA phylogeny of the Old-World monkey tribe Papionini. Mol Biol Evol 9:1-13

Eernisse DJ, Kluge AG (1993) Taxonomic congruence versus total evidence, and amniote phylogeny inferred from fossils, molecules, and morphology. Mol Biol Evol 10:1170-1195

Farris JS (1989) The retention index and rescaled consistency index. Cladistics 5:417-419

Felsenstein J (1978) Cases in which parsimony or compatibility methods will be positively misleading. Syst Zool 27:401-410

Felsenstein J (1985) Confidence limits on phylogenies: an approach using the bootstrap. Evolution 39:783-791

Flynn LJ, Jacobs LL, Cheema IU (1986) Baluchimyinae, a new ctenodactyloid rodent subfamily from the Miocene of Baluchistan. Am Mus Novitates 2841:1--58

Gadaleta G, Pepe G, De Candia G, Quagliariello C, Sbisa E, Saccone C (1989) The complete nucleotide sequence of the Rattus norvegicus mitochondrial genome: cryptic signals revealed by comparative analysis between vertebrates. J Mol Evol 28:497-516

Gentry AW (1992) The subfamilies and tribes of the family Bovidae. Mammal Rev 22:1-32

Graur D (1993) Molecular phylogeny and the higher classification of eutherian mammals. Trends Ecol Evol 8:141-147

Graur D, Hide WA, Li W-H (1991) Is the guinea-pig a rodent? Nature 351:649-652

Graur D, Higgins DG (1994) Molecular evidence for the inclusion of cetaceans within the order Artiodactyla. Mol Biol Evol 11:357-364

Green M, Bjork PR (1980) On the genus Dikkomys (Geomyoidea, Mammalia). Palaeovertebrata, Montpellier, Mem Jubil R Lavocat: 343-353

Holmes ES (1991) Different rates of substitution may produce different phylogenies of the eutherian mammals. J Mol Evol 33:209-215

Honeycutt RL, Adkins RM (1993) Higher level systematics of eutherian mammals: an assessment of molecular characters and phylogenetic hypotheses. Annu Rev Ecol Syst 24:279-305

Ikemura T (1985) Codon usage and tRNA content in unicellular and multicellular organisms. Mol Biol Evol 2:13-34

Irwin DM, Arnason U (1994) Cytochrome $b$ gene of marine mammals: phylogeny and evolution. J Mamm Evol 2:37-55

Irwin DM, Kocher TD, Wilson AC (1991) Evolution of the cytochrome $b$ gene of mammals. J Mol Evol 32:128-144
Irwin DM, Wilson AC (1992) Limitations of molecular methods for establishing the phylogeny of mammals, with special reference to the position of elephants. In: Szalay FS, Novacek MJ, McKenna MC (eds) Mammalian phylogeny. Springer-Verlag, New York, pp 257-267

Janis CM, Scott KM (1987) The interrelationships of higher ruminant families with special emphasis on the members of the Cervoidea. Am Mus Novit 2893:1-85

Janke A, Feldmaier-Fuchs G, Thomas WK, von Haeseler A, Paabo, S (1994) The marsupial mitochondrial genome and the evolution of placental mammals. Genetics 137:243-256

Jukes TH, Cantor CR (1969) Evolution of protein molecules. In: Munro HN (ed) Mammalian protein metabolism. Academic Press, New York, pp 21-132

Keohavang P, Thilly WG (1989) Fidelity of DNA polymerases in DNA amplification. Proc Natl Acad Sci USA 86:9253-9257

Kimura M (1980) A simple method for estimating evolutionary rates of base substitutions through comparative studies of nucleotide sequences. J Mol Evol 16:111-120

Kluge AG (1989) A concern for evidence and a phylogenetic hypothesis of relationships among Epicrates (Boidae, Serpentes). Syst Zool 38:7-25

Kraft R, Tardiff J, Krauter KS, Leinwand LA (1988) Using mini-prep plasmid DNA for sequencing double stranded templates with sequenase. Biotechniques 6:544-547

Kraus F, Miyamoto MM (1991) Rapid cladogenesis among the pecoran ruminants: evidence from mitochondrial DNA sequences. Syst Zool 40:117-130

Kumar S, Tamura K, Nei M (1993) MEGA: molecular evolutionary genetics analysis, version 1.02. Institute of Molecular Evolutionary Genetics, The Pennsylvania State University, University Park, Pennsylvania

Li W-H (1987) Models of nearly neutral mutations with particular implications for nonrandom usage of synonymous codons. J Mol Evol 24:337-345

Li W-H, Hide WA, Zharkikh A, Ma D-P, Graur D (1992) The molecular taxonomy and evolution of the guinea pig. J Hered 83:174-181

Li W-H, Tanimura M, Sharp PM (1987) An evaluation of the molecular clock hypothesis using mammalian DNA sequences. J Mol Evol 25:330-342

Luckett WP, Hartenberger J-L (1985) Evolutionary relationships among rodents: a multidisciplinary analysis. Plenum Press, New York, pp 1-721

Luckett WP, Hartenberger J-L (1993) Monophyly or polyphyly of the order Rodentia: possible conflict between morphological and molecular interpretations. J Mammal Evol 1:127-147

Ma D-P, Zharkikh A, Graur D, VandeBerg JL, Li W-H (1993) Structure and evolution of opossum, guinea pig, and porcupine cytochrome $b$ genes. J Mol Evol 36:327-334

Martin AP, Palumbi SR (1993) Body size, metabolic rate, generation time, and the molecular clock. Proc Natl Acad Sci USA 90:40874091

Mindell DP, Honeycutt RL (1990) Ribosomal RNA in vertebrates: evolution and phylogenetic applications. Annu Rev Ecol Syst 21: 541-566

Miyamoto MM, Allard MW, Adkins RM, Janecek LL, Honeycutt RL (1994) A congruence test of reliability using linked mitochondrial DNA sequences. Syst Biol 43:236-249

Miyamoto MM, Kraus F, Laipis PJ, Tanhauser SM, Webb SD (1993) Mitochondrial DNA phylogenies within Artiodactyla. In: Szalay FS, Novacek MJ, McKenna MC (eds) Mammalian phylogeny. Springer-Verlag, New York, pp 268-281

Miyamoto MM, Kraus F, Ryder OA (1990) Phylogeny and evolution of antlered deer determined from mitochondrial DNA sequences. Proc Natl Acad Sci USA 87:6127-6131

Novacek MJ (1992) Mammalian phylogeny: shaking the tree. Nature 356:121-125 
O'hUigin C, Li W-H (1992) The molecular clock ticks regularly in muroid rodents and hamsters. J Mol Evol 35:377-384

Pesole G, Sbisa E, Mignotte F, Saccone C (1991) The branching order of mammals: phylogenetic trees inferred from nuclear and mitochondrial molecular data. J Mol Evol 33:537-542

Pilgrim GE (1947) The evolution of the buffaloes, oxen, sheep, and goats. J Linnean Soc London (Zoology) 41:272-286

Pumo DE, Phillips CJ, Barcia M, Millan C (1992) Three patterns of mitochondrial DNA nucleotide divergence in the meadow vole, Microtus pennsylvanicus. J Mol Evol 34:163-174

Russell RJ (1968a) Evolution and classification of the pocket gophers of the subfamily Geomyinae. Univ Kansas Pub Mus Nat Hist 16: 473-597

Russell RJ (1968b) Revision of pocket gophers of the genus Pappogeomys. Univ Kansas Pub Mus Nat Hist 16:581-776

Ruvolo M, Disotell TR, Allard MW, Brown WM, Honeycutt RL (1991) Resolution of the African hominoid trichotomy by use of a mitochondrial gene sequence. Proc Natl Acad Sci USA 88:15701574

Saiki RK, Gelfand DH, Stoeffel S, Scharf SJ, Higuchi R, Horn GT, Mullis KB, Erlich HA (1988) Primer-directed enzymatic amplification of DNA with a thermostable DNA polymerase. Science 239: $487-491$

Saitou N, Nei M (1987) The neighbor-joining method: a new method for reconstructing phylogenetic trees. Mol Biol Evol 4:406-425
Savage DE, Russell DE (1983) Mammalian paleofannas of the world. Addison-Wesley, Reading, MA

Sharp PM, Cowe E, Higgins DG, Shields DC, Wolfe KH, Wright F (1988) Codon usage patterns in Escherichia coli, Bacillus subtilis, Saccharomyces cerevisiae, Schizosaccharomyces pombe, Drosophila melanogaster and Homo sapiens; a review of the considerable within-species diversity. Nucleic Acids Res 16:8207-8211

Shields DC (1990) Switches in species-specific codon preferences: the influence of mutation biases. J Mol Evol 31:71-80

Sidow A, Wilson AC (1991) Compositional statistics evaluated by computer simulations. In: Miyamoto MM, Cracraft J (eds) Phylogenetic analysis of DNA sequences. Oxford University Press, New York, pp 129-146

Swofford DL (1993) PAUP: phylogenetic analysis using parsimony, version 3.1. Illinois Natural History Survey, Champaign, Illinois

Tajima F, Nei M (1984) Estimation of evolutionary distance between nucleotide sequences. Mol Biol Evol 1:269-285

Tamura K, Nei M (1993) Model selection in the estimation of the number of nucleotide substitutions. Mol Biol Evol 10:512-526

Thomas WK, Martin SL (1993) A recent origin of marmots. Mol Phyl Evol 2:330-336

Tindall KR, Kunkel TA (1988) Fidelity of DNA synthesis by the Thermus aquaticus DNA polymerase. Biochemistry 27:6008-6013

Wu C-I, Li W-H (1985) Evidence for higher rates of nucleotide substitutions in rodents than in man. Proc Natl Acad Sci USA 82: $1741-1745$ 